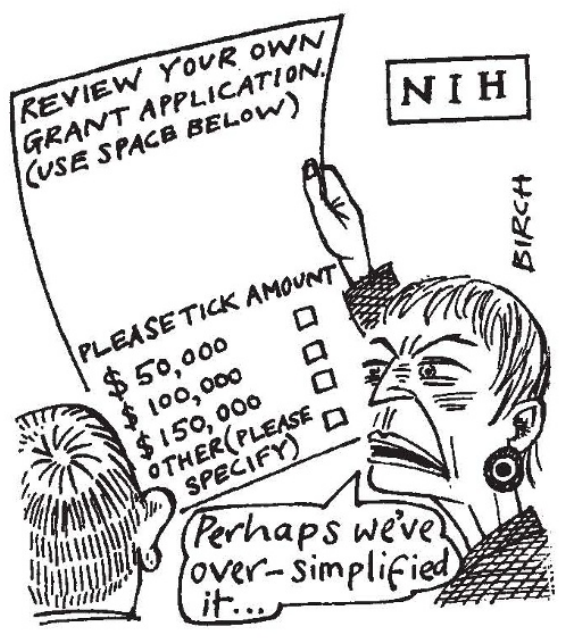

study sections also received close attention at the meeting. Alberts lent the weight of his office to the debate by pointing out that biology is changing more rapidly than the composition of the study sections. "Even when the study sections reflect the current fields in biology, their expertise decays and they cannot attract the likes of a Harold Varmus," he said.
His remarks stimulated nods of agreement. Ira Mellman, a professor in the department of cell biology at Yale University said that the composition of the study sections was the most important public policy decision facing NIH over how to spend its money. Asked later if he agreed with Mellman's assessment, Alberts said: "Yes, I like that."

The issue is to be addressed by Keith Yamamoto, chair of the department of pharmacology at the University of California, San Francisco, at a meeting in the autumn. Yamamoto points out that work on hormone receptors would once have involved only physiologists, but now it involves X-ray crystallographers, geneticists and developmental biologists.

$\mathrm{NIH}$ admits that it can be difficult to recruit people to study sections. Appointments last for four years, and are timeconsuming. The feeling at last week's meeting was that peer review carries the same civic responsibility as jury duty. Dissatisfaction was expressed with scientists who have received grants from the NIH yet refuse to serve as peer reviewers. Many can expect a personal phone call from Varmus during the coming months.

Helen Gavaghan

\title{
doubters over policy changes
}

But even with such reassurance, there remains concern that a commitment to pursue wealth creation will inevitably mean that, whatever peer-review judgement is made, the final decision on a particular grant application will also involve non-scientific criteria. According to the council, for example, even in the pre-screening of research applications, one of the three reviews will be expected to reflect the views of the potential 'users' of the results of the research.

More generally, there is unease among some scientists that the abolition of the council's scientific committees will deprive those engaged in the peer-review process of a chance to develop a proper overview of their discipline. "Peer review is not the centre of our concerns," says John Ringrose of the University of Newcastle upon Tyne, who is president of the London Mathematical Society, Britain's main body for professional mathematicians. "What worries us is that the EPSRC may adopt an approach to research and research training that takes little account of those involved in the peer review process."

According to Ringrose, for example, the only "coherent view" of a field will now be that held by programme managers. He and others suggest that this will inevitably shift the balance of power between the council (and its officials) and the scientific community when it comes to strategic decisions.

Council officials defend the new changes as part of their efforts to increase the efficiency with which research grants are han- dled. While playing down the extent to which the council has been motivated by government directives to reduce costs, one motivation has been the need to reduce administrative costs.

Brook denies that scientists have been deprived of an opportunity to inject their ideas into the policy-formulating process. He points out that this will now be done through the new 'technical opportunities panel' which, in parallel to a separate 'users panel', is being set up to advise the council on its strategic priorities.

Senior officials of all six research councils last week had a meeting with officers of the Royal Society in London, which had expressed concern at the potential threat to the tradition of reviewing applications purely on the basis of scientific excellence.

After the meeting, Sir Michael Atiyah, the president of the Royal Society, said that he had been "moderately assured". But he added that he was reserving final judgement until further details have been published of precisely how the new mechanisms are to be put into practice.

The EPSRC is planning to circulate its detailed proposals on issues such as the planned arrangements of the discipline-based 'colleges' soon, with a goal of introducing the new procedures on 1 January next year. Both Brook and Alan Rudge, chairman of the EPSRC, will discuss the proposals at open meetings throughout the country in September and October. These promise to be lively affairs.

David Dickson

\section{World Bank report slams Western-style university model}

London. The European model of higher education is inefficient, relies too heavily on government funding, and is inappropriate for developing countries, according to a World Bank study published last week.

Faced with a worldwide increase in demand, countries are having to maintain or improve standards of higher education at the same time as budgets are being cut. The crisis has been most acute in developing countries, says the report, where expanding student numbers have had a dramatic impact.

A contraction in student expenditure -in Sub-Saharan Africa, for example, this fell from an average of $\$ 6,300$ per student in 1980 to $\$ 1,500$ in 1988 - has meant that the quality of teaching and research in many countries has deteriorated "precipitously" says the report.

Higher education institutions in these countries are faced with overcrowding, deteriorating physical facilities, and lack of resources for textbooks, educational materials and basic laboratory consumables.

The report says that science and technology has been particularly badly affected in developing countries. This is reflected in the fall in scientific output. In Ghana, for example, the number of science papers published dropped by 67 per cent between 1977 and 1987; there was a decline of 53 per cent in Uganda over the same period.

The World Bank, which has lent US\$5.1 billion for higher education since 1980 , says that the solution lies in greater private financing of higher education, accompanied by improved efficiency and quality in publicly-funded institutes.

In particular, it wants reform to move in four key directions: encouraging a greater differentiation of institutions (including the development of private institutions); giving public institutions incentives to explore alternative sources of funding; redefining the role of the government; and introducing policies to give priority to quality and equity.

According to Thomas Eisemon, one of the report's authors and a senior specialist at the World Bank's education department, the decline in science research output, particularly in Africa, is the natural consequence of lack of resources. In some countries lecturers are having to supplement salaries as low as US $\$ 30$ per month by taking on additional jobs, while the buildings themselves fall into disrepair. As he says: "You can't teach biochemistry under a tree."

The controversial findings of the report echo feelings in post-communist east central Europe that countries should not emulate western university systems, but should instead learn by their mistakes (see Nature 369, 600; 1994).

Maggie Verrall 